\title{
Design of Student and Course Learning Outcomes Measurement
}

\author{
Hans Kristianto', Susiana Prasetyo², Ratna Frida Susanti ${ }^{3}$, \\ Mariskha Tri Adithia ${ }^{4}$ \\ 1,2,3 Department of Chemical Engineering, Parahyangan Catholic University, Bandung, Indonesia \\ ${ }^{4}$ Department of Informatics, Parahyangan Catholic University, Bandung, Indonesia \\ e-mail: hans.kristianto@unpar.ac.id ${ }^{1}$, susiana@unpar.ac.id²,$\underline{\text { santi@unpar.ac.id }}$, mariskha@unpar.ac.id
}

\begin{abstract}
Measurement of the outcomes becomes a vital part in OBE system to ensure the attainment of each outcome. In Indonesia, OBE was adopted in 2015 for higher education level. However, the changes were not accompanied with clear method to measure the outcomes, which became the urgency of this research. In this study, a preliminary method to measure student learning outcomes (SLO) and course learning outcomes (CLO) was presented. The measurement of SLO and CLO attainment was started by SLO mapping to courses, which usually had been done at curriculum design. Based on the mapping, formulation of CLO with a set of direct assessment was planned at the start of each course. After the teaching learning activities, a series of calculation was designed to obtain the attainment of SLO and CLO for each student, course, and whole study program. In the same time the final mark for GPA calculation of each student could also be obtained. The designed method could play an essential part in teaching-learning quality assurance and curriculum continuous improvement, which is aligned with both international and national accreditation criteria and standards. Furthermore, this study could provide insight for other study program in SLO and CLO attainment measurement.
\end{abstract}

Keywords: Learning Outcomes, Outcome Measurement

\section{Introduction}

Along with the enactment of Ministerial Regulation No 44 of 2015 from Ministry of Research, Technology and Higher Education, and revised by Ministerial Regulation no 3 of 2020 from Ministry of Education and Culture about national standard on higher education in Indonesia, all study programs are encouraged to change their curriculum towards outcome based education (OBE). This change is intended to improve teaching-learning process, where OBE curriculum emphasizes the mastery of student's knowledge, skills, and attitudes that would be needed after graduation (Biggs \& Tang, 2011), that reflected in the student learning outcomes (SLO). According to the Indonesian standard on higher education, there are 4 aspects of SLO, covering aspects of knowledge, attitudes, general and special skills (Makarim, 2020; Nasir, 2015). The achievement of SLO comes from the accumulation of student experience throughout various teaching-learning activities. Therefore, the attainment of SLO should be supported by attainments of specific course learning outcomes (CLO). SLO and CLO should be designed with regard to the depth and breadth by using learning taxonomy keywords that facilitate the design of learning activities and measurements (Biggs, 1996; Biggs \& Tang, 2011), as presented in Table 1.

Based on the Guidelines for Developing Higher Education Curriculum published by Indonesia Directorate General of Learning and Student Affairs in 2016, referring to AUN-QA, both SLO and CLO should be clear, observable, measurable, and achievable during learning process (Nurwardani et al., 2016). However, there is no instruction on how the SLO and CLO could be measured. The previously mentioned guideline book was then revised in 2018, however the measurement techniques and methods of SLO and CLO are still not included (Nurwardani et al., 2018). In the guidelines published by Directorate General of Higher Education in mid-2020, the calculation of CLO attainment is presented in the appendix, however without any comprehensive explanation. The calculation was based on averaging

\footnotetext{
${ }^{*}$ Corresponding author.

Received 03 October 2020; Accepted 05 November 2020; Available online 25 March 2021

(C) 2020 JPI. All Rights Reserved
}

Jurnal Pendidikan Indonesia (JPI) | 97 
method and only CLO was obtained, and its correlation to determine SLO attainment is still not present (Junaidi et al., 2020). Regarding the measurement of SLO, it is mentioned in the Ministerial Regulation no 3 of 2020 from Ministry of Education and Culture article 26 paragraph 4 "The results of the assessment of the learning outcomes of graduates in each semester is stated by semester GPA", and paragraph 5 "The results of the assessment of the learning outcomes of graduates at the end of study program is stated by cumulative GPA". Based on this regulation, the SLO is not measured specifically for each learning outcome, but in general form of semester and final GPA, thus not providing a clear picture of CLO attainment for each course and also SLO for each student and whole study program.

The measurement of learning outcomes' attainment is an important step in order to evaluate the course learning process and study program and furthermore becomes a key aspect to ensure continuous improvement and quality assurance in the learning process, study program's curriculum, program educational objectives, and even standardization in national education (Rajak, Shrivastava, \& Tripathi, 2019). It is known that continuous improvement and quality assurance are the key aspect of various international accreditation such as the Accreditation Board for Engineering and Technology (ABET) and the Institution of Chemical Engineering (IChemE), the Indonesian Accreditation Board for Engineering Education (IABEE), etc., and also National Accreditation Board for Higher Education with new accreditation criteria 4.0 (BAN-PT, 2019). Therefore, a method to measure student, course, and study program attainments is needed, which became the purpose of this study.

Generally, there are two ways to measure SLO and CLO, namely indirect and direct assessment (Zlatkin-Troitschanskaia, Shavelson, \& Kuhn, 2015). Indirect assessment comprised of surveys based on self-reported measurement (Douglass, Thomson, \& Zhao, 2012), while direct assessment is done by using examination or observation of student by the lecturers, such as in traditional grading system (Caspersen, Smeby, \& Aamodt, 2017). According to Caspersen et al. (2017), although there are some drawbacks of traditional grading system, such as subjectivity of grader, different standards used, etc., grading is still generally accepted and used to measure students' capability. In this paper, we proposed SLO and CLO measurement using direct assessment for Department of Chemical Engineering, Parahyangan Catholic University. The designed method was adopting traditional grading system that usually used to calculate student GPA, on the other hand also accommodate measurement of SLO and CLO for each student, course, and study program.

Table 1. Learning taxonomy for the design of SLO and CLO

\begin{tabular}{|c|c|c|}
\hline Taxonomy & Levels' keywords & Assessment \\
\hline $\begin{array}{l}\text { Cognitive (Bloom revised) } \\
\text { (Krathwohl, 2002) }\end{array}$ & $\begin{array}{l}\text { Remembering, understanding, } \\
\text { applying, analysing, evaluating, } \\
\text { creating }\end{array}$ & $\begin{array}{l}\text { Written or oral exam/ } \\
\text { quizzes, essays } \\
\text { accompanied with clear } \\
\text { solutions and grading } \\
\text { system }\end{array}$ \\
\hline $\begin{array}{l}\text { Affective (Krathwohl) } \\
\text { (Kasilingam, Ramalingam, } \\
\text { \& Chinnavan, 2014) } \\
\text { Concrete psychomotor } \\
\text { (Simson) (Kasilingam et } \\
\text { al., 2014) }\end{array}$ & $\begin{array}{l}\text { Accepting, responding, valuing, } \\
\text { organizing (internalizing), } \\
\text { characterizing (actualizing) } \\
\text { Perception (awareness), set, } \\
\text { guided response, mechanism } \\
\text { (basic proficiency), complex } \\
\text { overt response (expert), } \\
\text { adaptation, origination }\end{array}$ & $\begin{array}{l}\text { Observation by lecturer, } \\
\text { peer, or self-assessment } \\
\text { accompanied with rubric } \\
\text { Observation by lecturer } \\
\text { accompanied with rubric }\end{array}$ \\
\hline $\begin{array}{l}\text { Abstract psychomotor } \\
\text { (Dyers) (Dyers, Gregersen, } \\
\text { \& Christensen, 2011; } \\
\text { Widyartono, Dawud, } \\
\text { Ghazali, \& Harsiati, 2017) }\end{array}$ & $\begin{array}{l}\text { Observing, questioning, } \\
\text { experimenting, associating, } \\
\text { communicating }\end{array}$ & $\begin{array}{l}\text { Observation by lecturer } \\
\text { accompanied with rubric }\end{array}$ \\
\hline
\end{tabular}




\section{Method}

This study was done by following the first three steps of Borg and Gall model for product development, namely research and information collecting, planning, and development of preliminary form of product (Effendi \& Hendriyani, 2019). The research step focused on literature review in the techniques and needs of CLO and SLO measurement. In the second step, the method that would be designed was planned and its objectives were defined. Finally in the third step, the product in this study, namely the method to calculate CLO and SLO were designed. The typical first three steps from Borg and Gall model is presented in Figure 1.

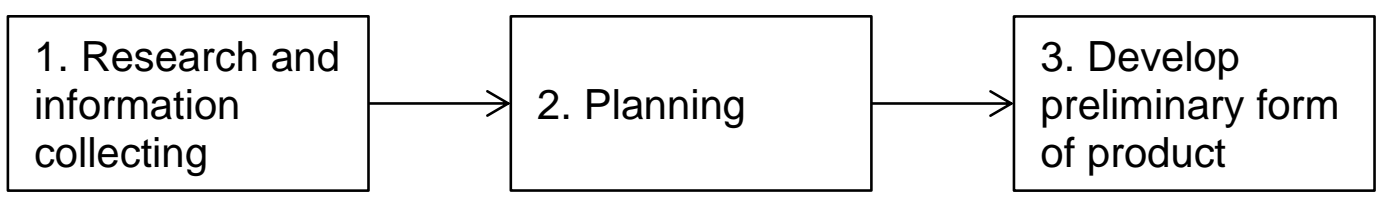

Figure 1. The first three steps of Borg and Gall model that used in this study (Effendi \& Hendriyani, 2019)

\section{Result and Discussion \\ Literature study and planning}

There are a number of studies regarding measurement of SLO and CLO that has been published and its summary is presented in Table 2 . It is notable that the measurement strategy that has been reported mainly focused on only SLO or CLO, which proofed to be insufficient, as a general evaluation of a study program should be based on SLO measurement which based on CLO measurement. While the measurement steps are done using similar approach, the SLO or CLO mapping method that has been reported also varied. Several researchers, such as Shafi et al. (2019), Mohamed et al. (2010), and Mohamed et al. (2008) used levels in the mapping to indicate the difference interaction between SLO - CLO or CLO - assessment, while other researchers did not.

There are also variations in the measurement method, namely direct and indirect assessment. Most of the researchers reported SLO and CLO measurement based on direct assessment in form of quizzes, assignments, tests, and exams. On the other hand, utilization of indirect assessment by instructor's feedback at the end of semester based on students' performance. Measurement of CLO using direct assessment and the result compared with indirect assessment. The indirect assessment was done by the students' perception on the CLO and marked using Likert scale (0-5). Based on the result, the indirect measurement seemed to be biased as 6 of 8 CLO are significantly higher than the direct assessment.

On the other hand, grading system using conversion of final marks that based on various direct assessments converted into GPA is still used in Indonesia, as written in Ministerial Regulation no 3 of 2020 from Ministry of Education and Culture article 26. Thus the designed system should also accommodate this system, as complicated outcomes measurement system could be exhaustive (Shafi et al., 2019). Reflecting on previous studies, and the regulation in Indonesia, the designed system would adopt SLO to CLO mapping without using levels and also direct assessment for measurement of SLO and CLO.

Table 2. Summary of researches related to SLO - CLO measurement

\begin{tabular}{lll}
\hline No & Findings & Reference \\
\hline 1 & Measured: SLO & (Shafi et al., \\
& Measurement steps: SLO mapping, assessment, and analysis & $2019)$ \\
& Usage of levels in SLO mapping: Introductory (I), Reinforced (R), & \\
& and Emphasized (E), differ in emphasizing of CLO and assessment & \\
& Measurement method: direct and indirect assessment &
\end{tabular}




\begin{tabular}{|c|c|c|}
\hline No & Findings & Reference \\
\hline 2 & $\begin{array}{l}\text { Measured: CLO } \\
\text { Measurement steps: CLO mapping o assessment, assessment, } \\
\text { and analysis } \\
\text { No levels in CLO mapping } \\
\text { Measurement method: direct assessment }\end{array}$ & $\begin{array}{l}\text { (Mustaffa, } \\
\text { Zulkifliand, \& } \\
\text { Murat, 2019) }\end{array}$ \\
\hline 3 & $\begin{array}{l}\text { Measured: CLO } \\
\text { Measurement steps: CLO formulation, CLO mapping to } \\
\text { assessment, assessment, and analysis } \\
\text { No levels in CLO mapping } \\
\text { Measurement method: direct and indirect assessment }\end{array}$ & $\begin{array}{l}\text { (Rahman \& } \\
\text { Abdullah, } \\
\text { 2013) }\end{array}$ \\
\hline 4 & $\begin{array}{l}\text { Measured: CLO } \\
\text { Measurement steps: CLO formulation, CLO mapping to } \\
\text { assessment, assessment and analysis } \\
\text { No levels in CLO mapping } \\
\text { Measurement method: direct assessment }\end{array}$ & $\begin{array}{l}\text { (Keshavarz, } \\
\text { 2011) }\end{array}$ \\
\hline 5 & $\begin{array}{l}\text { Measured: SLO and CLO } \\
\text { Measurement steps: CLO mapping to SLO and weightage, CLO } \\
\text { mapping to assessment, assessment, CLO and SLO attainment } \\
\text { Usage of levels in CLO to SLO mapping: } 3 \text { (strongly related), } 2 \\
\text { (medium related), and } 1 \text { (less related) } \\
\text { Measurement method: direct assessment }\end{array}$ & $\begin{array}{l}\text { (Z. Mohamed, } \\
\text { Taib, \& Reza, } \\
\text { 2010) }\end{array}$ \\
\hline 6 & $\begin{array}{l}\text { Measured: CLO } \\
\text { Measurement steps: CLO to topic mapping and weightage, } \\
\text { assessment, analysis using Rasch Model } \\
\text { Usage of levels in CLO to topic mapping: } 1 \text { (major), } 2 \text { (mediocre), } \\
\text { and } 3 \text { (minor) } \\
\text { Measurement method: direct assessment }\end{array}$ & $\begin{array}{l}\text { (A. Mohamed, } \\
\text { Abd.Aziz, } \\
\text { Ahlan, } \\
\text { Zakaria, \& } \\
\text { Masodi, 2008) }\end{array}$ \\
\hline
\end{tabular}

\section{Design of SLO and CLO measurement}

The measurement of SLO and CLO was started by mapping the courses into SLO. This step was done when the curriculum was designed. Based on the SLO and subject study materials, lectures designed the CLO and the suitable assessment method. The weight of each CLO was taken into consideration in this step. Based on the initial design, the lecturers then do the teaching learning activities for 14 weeks lecture plus 2 weeks' mid-term and final exam. The assessments collected then process for CLO and SLO calculation, and furthermore evaluation and continuous improvement of course and curriculum. The simple scheme of this process is presented in Figure 2.

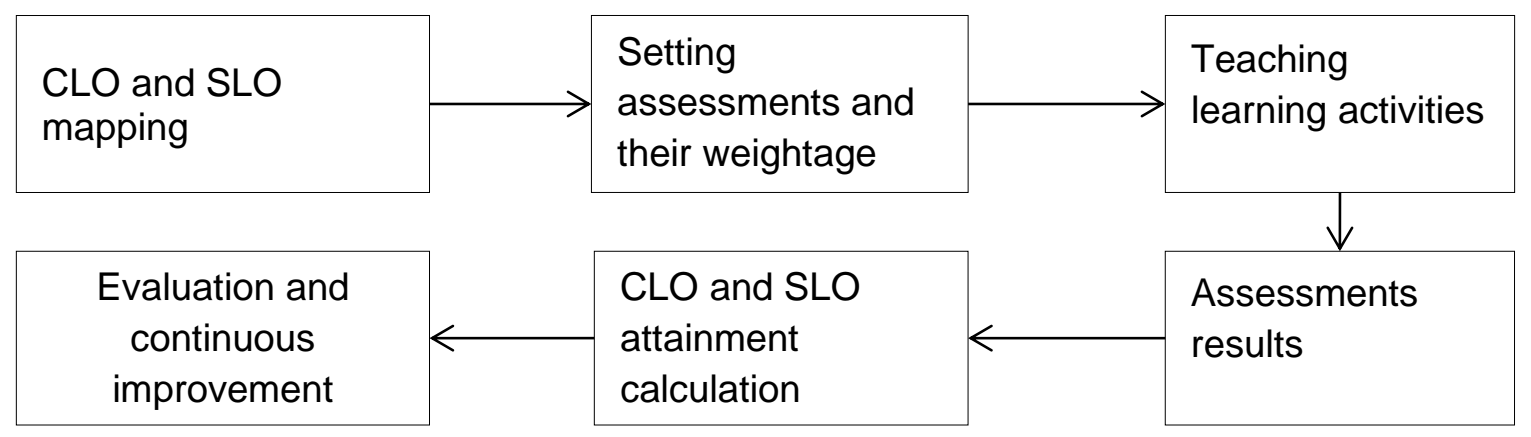

Figure 2. Flowchart of the design of CLO and SLO measurement 


\section{Mapping of courses, CLO and SLO}

To measure the attainment of CLO and SLO, first the lecturers have to map the courses into SLO, as illustrated in Table 3. The mapping was done based on the suitability of the courses and SLO. For example, a SLO of "ability to apply basic science knowledge" would be mapped to basic science courses (namely calculus, physic, chemistry) and maybe not suitable for engineering courses. To simplify, the mapping was done by giving a check mark to each suitable SLO, from the first (SLO1) till the $\mathrm{n}^{\text {th }}$ SLO (SLOn). This mapping system is different with previous researchers (A. Mohamed et al., 2008; Z. Mohamed et al., 2010) who use scale from 1 to 3 to illustrate low to strong contribution of courses to SLO. This was adopted to enable direct calculation from one mark table to obtain both traditional final mark and outcomes attainment. Furthermore, this approach is more simplistic and suitable for transition of traditional marking method to outcome ones.

Table 3. Courses to SLO mapping

\begin{tabular}{cccccccc}
\hline \multirow{2}{*}{ Course } & \multirow{2}{*}{ Credits } & \multicolumn{7}{c}{ SLO } \\
\cline { 2 - 8 } & SLO1 & SLO2 & SLO3 & SLO4 & $\ldots$ & SLOn \\
\hline Course 1 & credits 1 & $\sqrt{y}$ & $\sqrt{ }$ & - & - & - & - \\
Course 2 & credits 2 & - & $\sqrt{ }$ & $\sqrt{ }$ & - & $\ldots$ & $\sqrt{ }$ \\
Course 3 & credits 3 & $\sqrt{ }$ & $\ldots$ & $\ldots$ & $\ldots$ & $\ldots$ & $\ldots$ \\
$\ldots$ & $\ldots$ & $\ldots$ & $\ldots$ & $\ldots$ & $\ldots$ & $\ldots$ & $\ldots$ \\
Course n & credits $\mathrm{n}$ & $\sqrt{ }$ & $\ldots$ & $\ldots$ & $\ldots$ & $\ldots$ & $\ldots$ \\
\hline
\end{tabular}

After the courses were mapped to SLO, the CLO of each course were formulated, and the assessment methods that suitable for the CLO were also determined. An example of SLO, CLO, assessments and \%weight mapping is presented in Table 3. As presented in Table 1, the assessment could take form in tests, quizzes, oral exam, mid and end term tests for cognitive aspects, and observation for affective and psychomotor aspect. The \%weight of each assessment should be carefully considered, as it gave a picture of the CLO relation to SLO. Stronger relation of CLO to SLO would appear as bigger sum of \%weight, instead of giving high, medium, or low scale. Each SLO would have connection with at least one CLO. However, it was possible that one SLO could be measured by two or more CLO, and vice versa. This is illustrated as CLO1' and CLO1" in Table 4, indicating CLO1 was assigned to both SLO1 and SLO2, respectively. Several assessments could be done simultaneously by using one assessment activity. For example, a group student activity, such as problem based learning, project based learning, group discussion, laboratory work, etc. could measure cognitive, affective, and psychomotor aspects, thus measuring various CLO and SLO at one and the same time. Other example, quiz or mid-end term exam could also simultaneously measure several CLO and SLO of cognitive aspect. Based on these examples, the practice of OBE with SLO and CLO measurement does not mean that a lot of assessment activities are needed. Instead, a well-planned teaching learning activity is more important, so that both the students and lecturers would not be overwhelmed by too many assessments, tests, or assignments.

Table 4. Design of SLO, CLO, assessment and \%weight

\begin{tabular}{|c|c|c|c|}
\hline SLO & CLO & Assessment & $\%$ weight \\
\hline \multirow{4}{*}{ SLO1 } & CLO1' & Assessment 1 (A1) & $\% w 1$ \\
\hline & & Assessment 2 (A2) & \%w2 \\
\hline & CLO3 & Assessment 3 (A3) & \%w3 \\
\hline & & Assessment 4 (A4) & \%w4 \\
\hline \multirow{4}{*}{ SLO2 } & CLO1" & Assessment 5 (A5) & $\% w 5$ \\
\hline & & Assessment 6 (A6) & \%w6 \\
\hline & CLO2 & Assessment 7 (A7) & $\% w 7$ \\
\hline & & Assessment 8 (A8) & $\% w 8$ \\
\hline \multicolumn{3}{|c|}{ Total } & $100 \%$ \\
\hline
\end{tabular}




\section{CLO and SLO attainment calculation}

After the teaching and learning activities, one can make a table of all students' assessments results and their relation to the CLO and SLO, as planned before. The tabulation is presented in Table 5. It could be observed that Table 4 is accommodating the SLO, CLO, and \%weight, with addition of student names (N1 to Nn), maximum mark of each assessment ( $\mathrm{m} 1$ to $\mathrm{m} 8$ ), and students' mark for each assessment (N1,a1 to $\mathrm{Nn}, \mathrm{a} 8)$. The maximum mark should be carefully planned, as it is used in calculation of final mark (FM1 to FMn).

Table 5. Tabulation of students' mark to respective CLO and SLO

\begin{tabular}{|c|c|c|c|c|c|c|c|c|c|}
\hline \multirow{5}{*}{ Name } & \multicolumn{4}{|c|}{ SL01 } & \multicolumn{4}{|c|}{ SLO2 } & \multirow{3}{*}{$\begin{array}{l}\text { Final } \\
\text { mark } \\
\text { (FM) }\end{array}$} \\
\hline & \multicolumn{2}{|c|}{ CLO1' } & \multicolumn{2}{|c|}{ CLO3 } & \multicolumn{2}{|c|}{ CL01" } & \multicolumn{2}{|c|}{ CLO2 } & \\
\hline & A1 & A2 & A3 & A4 & A5 & A6 & A7 & A8 & \\
\hline & \%w1 & \%w2 & \%w3 & \%w4 & \%w5 & \%w6 & \%w7 & \%w8 & \\
\hline & m1 & $\mathrm{m} 2$ & m3 & m4 & m5 & $\mathrm{m} 6$ & m7 & $\mathrm{m8}$ & 100 \\
\hline N1 & $\mathrm{N} 1, \mathrm{a} 1$ & $\mathrm{~N} 1, \mathrm{a} 2$ & N1, a3 & $\mathrm{N} 1$, a4 & $\mathrm{N} 1$, a5 & $\mathrm{N} 1, \mathrm{a} 6$ & N1, a7 & N1,a8 & FM1 \\
\hline N2 & $\ldots$ & $\ldots$ & $\ldots$ & $\ldots$ & $\ldots$ & $\ldots$ & $\ldots$ & $\ldots$ & FM2 \\
\hline N3 & $\ldots$ & $\ldots$ & $\ldots$ & $\ldots$ & $\ldots$ & $\ldots$ & $\ldots$ & $\ldots$ & FM3 \\
\hline$\ldots$ & $\ldots$ & $\ldots$ & $\ldots$ & $\ldots$ & $\ldots$ & $\ldots$ & $\ldots$ & $\ldots$ & $\ldots$ \\
\hline $\mathrm{Nn}$ & $\mathrm{Nn}, \mathrm{a} 1$ & $\ldots$ & $\ldots$ & $\ldots$ & $\ldots$ & $\ldots$ & $\ldots$ & $\mathrm{Nn}, \mathrm{a8}$ & FMn \\
\hline
\end{tabular}

After the tabulation of students' marks was completed, the \% attainment of CLO for each student could be calculated following the equation (1). After the CLO were calculated, the SLO for each student could be determined using equation (2). The SLO was calculated based on the CLO which contributed to the SLO. For example, SLO1 for student N1 calculated from the CLO1' that was consisted of assessment 1 and 2 only, not included assessment 5 and 6. The calculation process was repeated until all students CLO and SLO' attainment were measured. Lastly, the FM for each student is calculated following equation (3). The FM should be calculated to determine student's grade point average (GPA), which is regulated by the Ministry of Education and Culture ion through Ministerial Regulation no 3 of 2020. Based on this regulation, our university adopted grading criteria through rector's regulation as shown in Table 6. As we have mentioned before, by incorporating traditional grading system combined with $\mathrm{OBE}$, we could satisfy both regulation and OBE system. Based on this regulation as well, the minimum attainment of CLO and SLO is determined to be $50 \%$, equivalent to FM 50 .

\%attainment of $N 1, C L O 1=\frac{(N 1, a 1) \times \% w 1+(N 1, a 2) \times \% w 2+(N 1, a 5) \times \% w 5+(N 1, a 6) \times \% w 6}{m 1 \times \% w 1+m 2 \times \% w 2+m 5 \times \% w 5+m 6 \times \% w 6} \times 100 \%$
$\%$ attainment of $N 1, S L O 1=\frac{\% N 1, C L O 1, \times(\% w 1+\% w 2)+\% N 1, C L O 3 \times(\% w 3+\% w 4)}{(\% w 1+\% w 2)+(\% w 3+\% w 4)}$

Final mark $(F M)=\frac{N 1, a 1}{m 1} \times \% w 1+\frac{N 1, a 2}{m 2} \times \% w 2+\cdots+\frac{N 1, a 8}{m 8} \times \% w 8$

Based on previously determined CLO and SLO, one could determine the CLO and SLO course by averaging the \%attainment of all students, as illustrated in equation (4). Furthermore, accumulation of SLO's \%attainment for whole curriculum could be calculated by taking the courses' credits into account, as shown in equation (5). This equation could also be used to calculate SLO for each student. The courses that included in this calculation were the one that contribute to the achievement of SLO, as previously mapped in Table 3.

$\%$ attainment of CLO1 $=\frac{(N 1, C L O 1)+(N 2, C L O 1)+\cdots+(N n, C L O 1)}{n}$ 
$\%$ attainment of SLO1 $=\frac{(\text { course } 1 \times \text { credits } 1)+(\text { course } 3 \times \text { credits } 3)+\cdots+(\text { course } n \times \text { credits } n)}{\sum \text { credits }}$

Table 6. Grading system in Parahyangan Catholic University

\begin{tabular}{ccc}
\hline Final mark & Grade code & GPA (out of 4.00) \\
\hline $80-100$ & A & 4.00 \\
$77-79$ & A- & 3.67 \\
$73-76$ & B+ & 3.33 \\
$70-72$ & B & 3.00 \\
$67-69$ & B- & 2.67 \\
$63-66$ & C+ & 2.33 \\
$60-62$ & C & 2.00 \\
$50-59$ & D & 1.00 \\
$<50$ & E & 0.00 \\
\hline
\end{tabular}

Based on the calculation results that have been explained above, one could extract various data, such as attainment of CLO per course per semester, changes of a CLO per course from time to time, SLO per student per semester or at the end of his/her study, etc. as illustrated in Figure 3. Student attainment level that generated at the end his/her study is furthermore translated as descriptive words, e.g. exemplary, accomplished, competent, developing, and unsatisfactory, for each of the SLO. In Indonesia, such description could be presented in document of "Diploma Supplement" (Santoso et al., 2015).
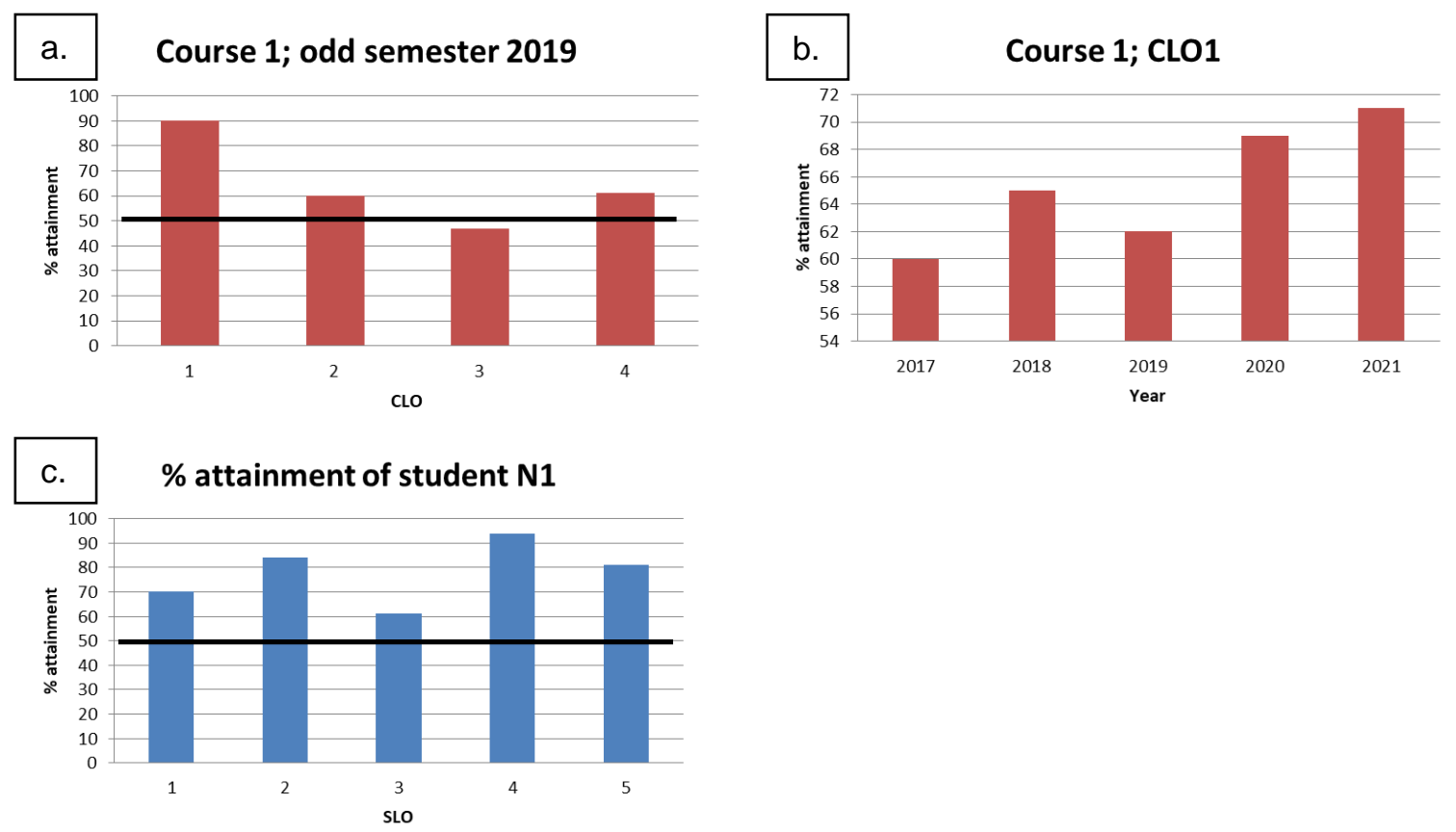

Figure 3. Illustration for CLO measurement per course per semester (a), CLO per course from year to year (b), and SLO attainment per student (c)

\section{Discussions and potential application in continuous improvement}

Based on the designed SLO - CLO attainment measurement method, the output of the calculation from this method are: final mark per student to be converted to GPA, CLO - SLO per course, overall SLO attainment for the study program, and SLO per student for both each semester and whole period of one's study. In the designed method, averaging method is still used with different approach for course SLO and CLO calculation. The calculation was started by SLO and CLO for each student first. This step is important to do in order to acquire attainment information for each student that is needed for the student's Diploma Supplement. 
This approach was different from one that was reported by previous researchers (Junaidi et al., 2020; Keshavarz, 2011; Mustaffa et al., 2019) as previous methods only focus on obtaining the CLO.

For the measurement of SLO attainment for the study program, the contribution of each course to the study program was determined by using the course credit. This approach was used by assuming that the credit of a course is proportional to the study load, and thus the effort of SLO attainment. This assumption was also used for the calculation of SLO per student for the whole study period. This approach was different from several researchers (Z. Mohamed et al., 2010; Shafi et al., 2019) that used levels to link the SLO attainment in a course to overall study program or student whole study period. Thus, compared to previous researchers the designed method provides more simple approach to measure attainment of learning outcome.

Calculation of the SLO and CLO attainment is the first step for continuous improvement of teaching learning process (Figure 4) that is an integral part of quality assurance. After measurement of CLO and SLO, the lecturers should do self-evaluation that is written in the form of course portfolio. In this portfolio, the lecturers could give comments and recommendations to improve students' performance and CLO - SLO attainment in the future. Various improvements that could be implemented such as, teaching-learning activities, course's syllabus, assessments and rubrics, recommendations related to other courses, etc. (Shafi et al., 2019). Furthermore, the courses' portfolios should be well documented, as it could be used for periodical curriculum evaluation. In addition to internal cycle for continuous improvement, curriculum design and evaluation should also give attention to external factors, namely: government regulations, accreditation standards, professional societies, and stakeholders such as employers and alumni. Input from employers, both in form of satisfaction survey and industrial board, could give insight to the expected competencies from graduates, and the gap to the existing condition (Fletcher, Sharif, \& Haw, 2017; Kondo \& Fair, 2017). This gap is then perceived as required changes and refinement in the curriculum. Alumni, through alumni research, also plays important role in curriculum evaluation and improvement, as they could point out required skills and knowledge competencies, based on their working experience (Saunders-Smits \& Graaff, 2012). All these strategies are following the plan-docheck-act (PDCA) cycle to actualize continuous improvement of both the courses and the curriculum could contribute to achievement of the program educational objectives (PEOs) (Tshai, Ho, Yap, \& Ng, 2014).

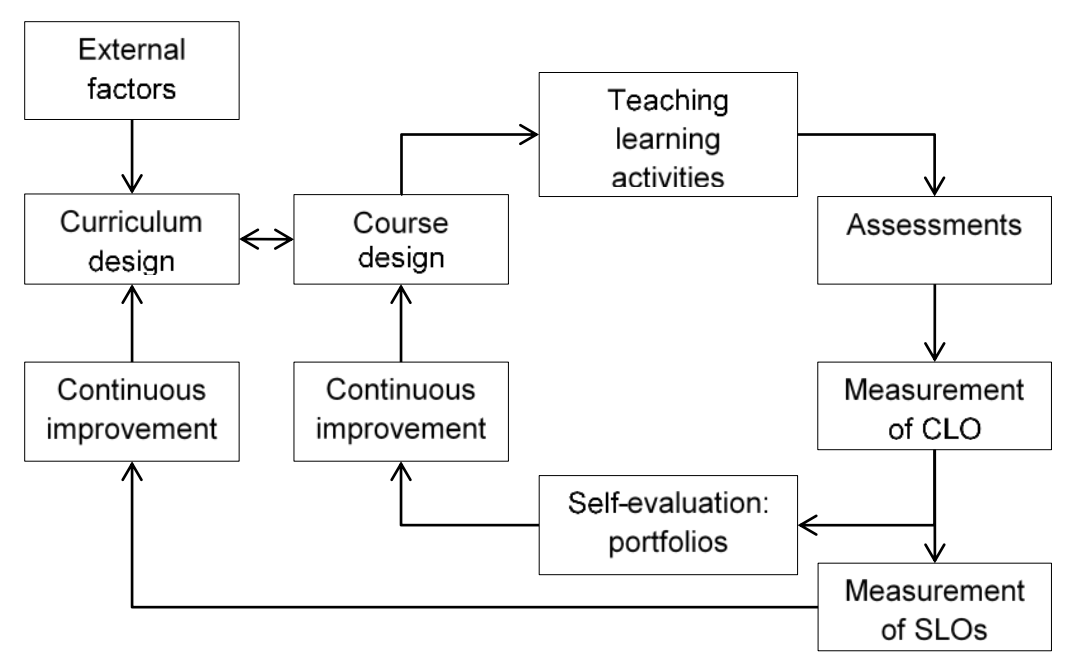

Figure 4. Measurement of CLO and SLO as part for continuous improvement (Adapted from (Garry, 2015). 


\section{Conclusions and Suggestions}

In this paper we proposed a design to measure attainment of CLO and SLO by adopting direct assessment with consideration of authentic assessment, following the learning taxonomies. The designed method could satisfy traditional grading system and outcome measurement. The involving steps are course mapping to SLO, designing CLO and assessments, calculation of CLO and SLO, and finally the course evaluation. The system that have been designed could play an important part of the teaching-learning quality assurance, and furthermore for continuous improvement of courses and program's curriculum. The designed method could provide insight for study programs in Indonesia in regards of SLO and CLO attainment measurement.

\section{References}

BAN-PT. (2019). Panduan untuk Mempersiapkan Evaluasi Diri Akreditasi 4.0. Jakarta.

Biggs, J. (1996). Enhancing teaching through constructive alignment. Higher Education, 32, 347-364. https://doi.org/10.1007/BF00138871.

Biggs, J., \& Tang, C. (2011). Teaching for Quality Learning at University (4th ed.). McGrawHill. Caspersen, J., Smeby, J. C., \& Olaf Aamodt, P. (2017). Measuring learning outcomes. European Journal of Education, 52(1), 20-30. https://doi.org/10.1111/ejed.12205.

Douglass, J. A., Thomson, G., \& Zhao, C.-M. (2012). The learning outcomes race: the value of self-reported gains in large research universities. Higher Education, 64 (3), 317-335. https://doi.org/10.1007/s10734-011-9496-x.

Dyers, J. H., Gregersen, H., \& Christensen, C. M. (2011). Innovators DNA. https://hbr.org/2009/12/the-innovators-dna.

Effendi, H., \& Hendriyani, Y. (2019). The Conceptual and Hypothetical Model of Interactive Blended Problem Based Learning. Jurnal Pendidikan Indonesia, 8(2), 285-292. http://dx.doi.org/10.23887/jpi-undiksha.v8i2.24162.

Fletcher, A. J., Sharif, A. W. A., \& Haw, M. D. (2017). Using the perceptions of chemical engineering students and graduates to develop employability skills. Education for Chemical Engineers, 18, 11-25. https://doi.org/10.1016/j.ece.2016.07.001.

Garry, B. (2015). Developing a Sustainable ABET Continuous Improvement Plan. Paper presented at the 2015 ASEE Zone III Conference.

Junaidi, A., Wulandari, D., Arifin, S., Soetanto, H., Kusumawardani, S. S., Wastutiningsih, S. P., Utama, M. S., Cahyono, E., Hertono, G. F., Syam, N. M., WY, H. J., Putra, P. H., Wijayanti, C., \& Jobih. (2020). Panduan Penyusunan Kurikulum Pendidikan Tinggi di Era Industri 4.0 untuk Mendukung Merdeka Belajar-Kampus Merdeka. Direktorat Jenderal Pendidikan Tinggi Kementerian Pendidikan dan Kebudayaan.

Kasilingam, G., Ramalingam, M., \& Chinnavan, E. (2014). Assessment of learning domains to improve student's learning in higher education. Journal of Young Pharmacists, 6(4), 27-33.

Keshavarz, M. (2011). Measuring Course Learning Outcomes. Journal of Learning Design, 4(4), 1-9. https://eric.ed.gov/?id=EJ963323.

Kondo, A. E., \& Fair, J. D. (2017). Insight into the Chemistry Skills Gap: The Duality between Expected and Desired Skills. Journal of Chemical Education, 94(3), 304-310. https://doi.org/10.1021/acs.jchemed.6b00566.

Krathwohl, D. R. (2002). A revision of Bloom's Taxonomy: An overview. Theory into Practice, 41(4), 212-218. https://doi.org/10.1207/s15430421tip4104_2.

Makarim, N. A. (2020). Peraturan Menteri Pendidikan dan Kebudayaan no 3 tahun 2020 tentang Standard Nasional Pendidikan Tinggi. Kementerian Pendidikan dan Kebudayaan.

Mohamed, A., Abd.Aziz, A., Ahlan, A. R., Zakaria, S., \& Masodi, M. (2008). Outcome Based Education Performance Measurement: A Rasch-based Longitudinal Assessment 
Model to measure Information Management Courses LO's WSEAS Transactions on Information Science and Applications, 5(3), 292-299. https://doi.org/10.5555/1467006.1467017.

Mohamed, Z., Taib, M. Y., \& Reza, M. S. (2010). Assessment Method for Course Outcome and Program Outcome In Outcome Based Education (OBE). Paper presented the Malaysian Technical Universities Conference on Engineering and Technology, Malaysia.

Mustaffa, N. A., Zulkifliand, M., \& Murat, R. I. Z. (2019). Measuring Course Learning Outcome for Large Class of Introductory Statistics Course. International Journal of Innovative Technology and Exploring Engineering, 8, 382-388.

Nasir, M. (2015). Peraturan Menteri Riset, Teknologi, dan Pendidikan Tinggi no 44 tentang Standard Nasional Pendidikan Tinggi. Jakarta: Kementerian Riset Teknologi dan Pendidikan Tinggi.

Nurwardani, P., Nugroho, S. W., Mulyono, E., Arifin, S., Djajanto, L., Soetanto, H., Kusumawardani, S. S., Wastutiningsih, S. P., Utama, M. S., Cahyono, E., Priyautama, F., Afriyudianto, Oscar, R., Prioningsih, Y., \& Furkan, N. (2016). Panduan Penyusunan Kurikulum Pendidikan Tinggi. Direktorat Jenderal Pembelajaran dan Kemahasiswaan, Kementerian Riset Teknologi dan Pendidikan Tinggi.

Nurwardani, P., Nugroho, S. W., Mulyono, E., Arifin, S., Djajanto, L., Soetanto, H., Kusumawardani, S. S., Wastutiningsih, S. P., Utama, M. S., Cahyono, E., Priyautama, F., Afriyudianto, Oscar, R., Prioningsih, Y., \& Furkan, N. (2018). Panduan Penyusunan Kurikulum Pendidikan Tinggi di Era Industri 4.0. Direktorat Jenderal Pembelajaran dan Kemahasiswaan, Kementerian Riset Teknologi dan Pendidikan Tinggi.

Rahman, N. A., \& Abdullah, S. R. S. (2013). Assessment Tool of Course Learning Outcomes for Mechanical Design of Process Equipment. Procedia Social and Behavioral Sciences, 102, 116-121. https://doi.org/10.1016/j.sbspro.2013.10.721.

Rajak, A., Shrivastava, A. K., \& Tripathi, A. K. (2019). An Approach to Evaluate Program Outcomes and Program Educational Objectives through Direct and Indirect Assessment Tools. International Journal of Emerging Technologies in Learning, 14(23), 85-97. https://www.learntechlib.org/p/217241/.

Santoso, M., Putra, A., Muhidong, J., Sailah, I., Mursid, S., Rifandi, A., Susetiawan, \& Endrotomo. (2015). Surat Keterangan Pendamping ljazah. Direktorat Jenderal Pembelajaran dan Kemahasiswaan, Kementerian Riset Teknologi dan Pendidikan Tinggi.

Saunders-Smits, G., \& Graaff, E. d. (2012). Assessment of curriculum quality through alumni research. European Journal of Engineering Education, 37(2), 133-142. https://doi.org/10.1080/03043797.2012.665847.

Shafi, A., Saeed, S., Bamarouf, Y. A., Iqbal, S. Z., Min-Allah, N., \& Alqahtani, M. A. (2019). Student Outcomes Assessment Methodology for ABET Accreditation: A Case Study of Computer Science and Computer Information Systems Programs. IEEE Access, 7, 13653-13667. https://ieeexplore.ieee.org/abstract/document/8620683.

Tshai, K. Y., Ho, J. H., Yap, E. H., \& Ng, H. K. (2014). Outcome-based Education - The Assessment of Programme Educational Objectives for an Engineering Undergraduate Degree. Engineering Education, 9(1), 74-85. https://doi.org/10.11120/ened.2014.00020.

Widyartono, D., Dawud, Ghazali, A. S., \& Harsiati, T. (2017). Cognitive, Psychomotor, and Affective Domain in Instruction on Writing Papers At University. International Journal of Social Science Humanity, 4(11), 4144-4148.

Zlatkin-Troitschanskaia, O., Shavelson, R. J., \& Kuhn, C. (2015). The international state of research on measurement of competency in higher education. Studies in Higher Education, 40(3), 393-411. https://doi.org/10.1080/03075079.2015.1004241. 